\title{
İşletmelerde Stratejik Yönlülük Boyutları ile Hizmet Yenilik Yeteneği ve Pazar Performansı Arasındaki İlişki: Bir Araştırma \\ (The Relationship Between Strategic Orientation Dimensions and Service Innovation Capability and Market Performance in Businesses: A Research)
}

\author{
Nurhan PAPATYA a Gürcan PAPATYA iD b Buğra HAMŞIOĞLU iD c \\ a Isparta Süleyman Demirel Üniversitesi, İktisadi ve İdari Bilimler Fakültesi, Isparta, Türkiye. nurhanpapatya@sdu.edu.tr \\ b Isparta Süleyman Demirel Üniversitesi, İktisadi ve İdari Bilimler Fakültesi, Isparta, Türkiye. gurcanpapatya@sdu.edu.tr \\ c Burdur Mehmet Akif Ersoy Üniversitesi, İktisadi ve İdari Bilimler Fakültesi, Burdur, Türkiye. abhamsioglu@mehmetakif.edu.tr
}

\begin{tabular}{|c|c|}
\hline MAKALE BİLGİSİ & ÖZET \\
\hline $\begin{array}{l}\text { Anahtar Kelimeler: } \\
\text { Stratejik Yönlülük Bo }\end{array}$ & $\begin{array}{l}\text { Amaç - Makalenin amacı Antalya ili üretim işletmelerinde stratejik yönlülük boyutları ile hizmet } \\
\text { yenilik yeteneği ve pazar performansı arasındaki ilişkiyi belirlemektir. }\end{array}$ \\
\hline $\begin{array}{l}\text { Hizmet Yeniliği } \\
\text { Pazar Performans }\end{array}$ & $\begin{array}{l}\text { Yöntem - Makalede, kullanılan ölçekler şu şekildedir: Müsşteri yönlülük ölçeği Despande ve Farley } \\
\text { (1998); rakip yönlülük ölçeği Narver ve Slater (1990) ile Olson vd. (2005); maliyet yönlülük ölçeği } \\
\text { Olson vd. (2005) ile Homburg vd (1999); hizmet yenilik yeteneği ölçeği Grawe vd. (2009) ve pazar } \\
\text { performansı da, Claycomb vd. (1999) ile Jaworski ve Kohli (1993) tarafından yapllan makaleden } \\
\text { yararlanılarak oluşturulmuştur. Araştırmanın ana kütlesi Antalya ilinde faaliyet gösteren ve Ticaret }\end{array}$ \\
\hline $\begin{array}{l}\text { Gönderilme Tarihi } 15 \text { Eylül } \\
2020\end{array}$ & $\begin{array}{l}\text { ve Sanayi Bakanlığı'na kayıtlı } 879 \text { işletme olarak belirlenmiş; araştırma, katılmayı kabul eden } 180 \\
\text { işletme ile görüşülerek gerçekleştirilmiştir. Elde edilen verilere kısmi en küçük kareler yöntemi ve } \\
\text { model testi uygulanmış, elde edilen bulgular değerlendirilmiş ve yorumu yapılmıştır. }\end{array}$ \\
\hline Kabul Tarihi 14 Aralık 2020 & $\begin{array}{l}\text { Bulgular - Stratejik yönlülük boyutları (müşteri yönlülük, rakip yönlülük, maliyet yönlülük), } \\
\text { hizmet yenilik yeteneği ve pazar performansı arasında ilişkilerin analizinde; stratejik yönlülük } \\
\text { boyutlarının hizmet yenilik yeteneğini doğrudan ve pozitif yönde etkilediği görülmüştür. Ayrıca } \\
\text { hizmet yenilik yeteneğinin pazar performansını doğrudan ve pozitif yönde etkilediği ve oluşturulan } \\
\text { araştırma hipotezleri ve modeli tam olarak doğrulandığı izlenmiştir. }\end{array}$ \\
\hline & $\begin{array}{l}\text { Tartışma - Bu araştırmada stratejik yönlülük boyutları, hizmet yenilik yeteneği ve pazar } \\
\text { performansı Türkiye ve Antalya ili özelinde ampirik olarak incelemiş ve elde edilen bulgular } \\
\text { tartışılmıştır. }\end{array}$ \\
\hline
\end{tabular}

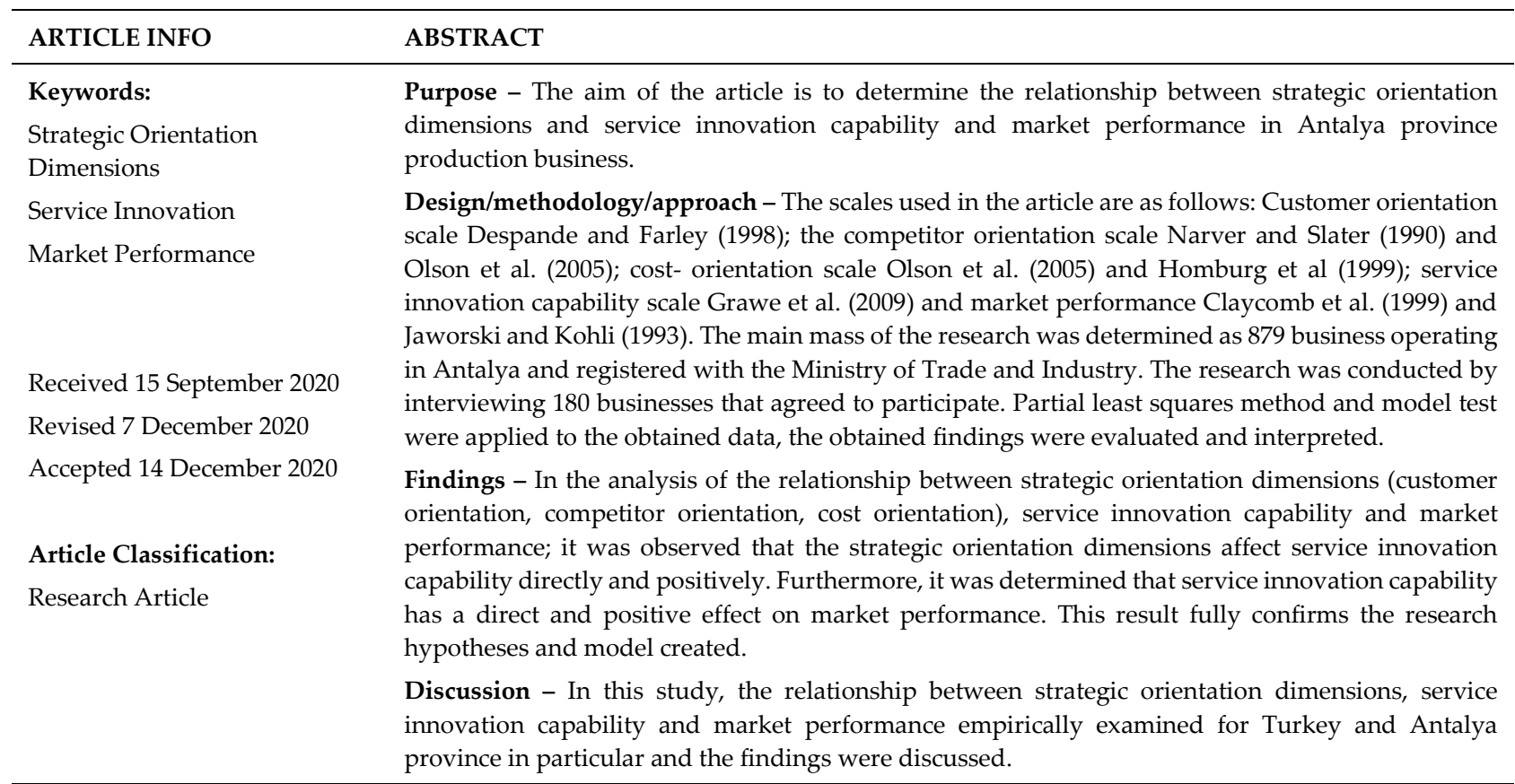

\section{Önerilen Atıf/ Suggested Citation}

Papatya, N., Papatya, G., Hamşığlu, B. (2020). İşletmelerde Stratejik Yönlülük Boyutları ile Hizmet Yenilik Yeteneği ve Pazar Performansı Arasındaki İlişki: Bir Araştırma, İşletme Araştırmaları Dergisi, 12 (4), 4051-4064. 


\section{GİRİS}

İşletme yöneticilerinin stratejik davranışlarına farklı vurgular yapılır ve çoğunlukla stratejik yönlülüğe bağlı değerlendirilir (Olson vd., 2005). Sözgelimi, müşteri yönlülük işletmelerin müşteri değeri yaratmasına ve sürdürmesine vurgu yapar. Rakip yönlülük işletmeleri hedeflenen rakipleri derinlemesine değerlendirmeyi teşvik eder, maliyet yönlülük ise, değer zinciri boyunca verimliliği takip eder (Porter, 1985; Day, 1990). Ancak stratejik yönlülük boyutlarının her biri birbirini dışlamaz ve bu durumda işletmeler aynı anda birden çok stratejik davranışta bulunabilir (Gatignon ve Xuereb, 1997).

Stratejik yönlülük, somut olmayan kaynakları temsil eden örgüt kültürünün bir yansımasıdır ve gelecek performansı yaratmaya dönüktür. Diğer bir deyişle işletmeninin istenen sonuçlara ulaşmak için maddi olmayan kaynaklara odaklanma ifadesidir. Kaynaklar ise, yeteneklerin ve yeniliğin temelidir (Narver ve Slater, 1990; Barney, 1991; Grant, 1991; Deshpande vd., 1993; Day, 1994; Hurley ve Hult, 1998). Yenilik de performansı nitelemektedir (Papatya vd., 2014). Bu nedenle yenilik, performans ile ilişkilendirilebilir ve ampirik olarak test edilebilir.

Artık bugün işletmeler dünden daha fazla ürün yeniliğinden ziyade hizmet yenilik sürecini nasıl yöneteceği konusunda düşünmesi gerekmektedir. Özellikle hizmet yenilik odaklılığın yeni organizasyon yapısını ve yeni yeteneklere geçiş içerimi göz önüne alındığında, önem daha anlaşılabilir bir durum yaratır. Bu açıdan işletmelerin hizmet yenilik boyutunda sürekli yeni hizmetler geliştirme ve hizmet sunumu mantığını kavrayabilmek için yenilikçi yeteneklere olan ihtiyacı çoğalmaktadır (Kindström vd., 2013).

Son dönem alan yazınında yeniliğin hizmet boyutu özgül olarak vurgulanır ve işletme pazar performansını artıran ve rekabet avantajına katkı sağlayan bir kavram olarak düşünülür (Damanpour ve Evan, 1984; Khan ve Manopichetwattana, 1989; Kandampully, 2002; Chapman vd., 2003; Berry vd., 2006; Kindström vd., 2013; Gronroos, 2015; Ta-Wei vd., 2015; Nada ve Ali, 2015; Jayani ve Hui, 20018). Hizmet yenilik boyutu sürdürülebilir rekabet avantajı sağlamada, zamanla değerli kaynakları ve yetenekleri yaratma, genişletme ve değiştirme yeteneği olarak görülür. Böylece bir bakıma üstün pazar performansı ve rekabet avantajı sağlanacağı vurgulanır (Kindström vd., 2013).

Bu makale işletmelerde stratejik yönlülük boyutları ile hizmet yeniliği ve pazar performansı arasındaki ilişkiyi araştırmayı ve test etmeyi amaçlamaktadır. Makalede ilgili alan yazınına bağlı, oluşturulan kavramsal çerçeve ile ortaya konan araştırma modeli hipotezleri sınanmakta ve sonuç düşünceleri vurgulanmaktadır.

\section{Kavramsal Çerçeve}

\subsection{Stratejik Yönlülükk Boyutlanı}

Stratejik yönlülük, işletmenin sürekli üstün pazar performansı elde etmek için uygun ve uygulanan stratejik davranışı ifade etmektedir. Stratejik davranış, pazar genelinde örgütlenme, yayılma ve pazar istihbarat kullanımı ile ilgilidir (Narver ve Slater, 1990; Sinkula, 1994; Baker ve Sinkula, 1999; Menguc ve Auh, 2005) ve pazarda güçlü bir konum için sürekli olarak müşterilere üstün değer sunumu hedefine yöneliktir.

Stratejik yönlülük uzun vadede işletmenin nasıl iş yapacağına ve müşterilere üstün değer nasıl üretileceğine kısaca sürdürülebilir rekabet avantajına dair çabalara rehberlik eder. Ayrıca işletme yöneticilerin çevreyi doğru algılamasını ve çevresel koşullarına olgun tepki vermesini destekler. Bu hali ile stratejik yönlülük işletmenin pazarlama ve strateji oluşturma faaliyetlerini etkileyen temel ilkeler arasında yer alır (Hamşığlu, 2017; Gotteland vd., 2020). Doğal olarak bu üstün performansa yol açan uygun stratejik davranışlar için işletme tarafından uygulanan stratejik yönergeleri etkiler ve işletmenin köklü değer ve inanç kümesi aracıllğı ile işin nasıl yürütüleceğine ilişkin felsefeye odaklanır (Thedosiou vd., 2012; Alobaidi ve Kitapc1, 2019). Bu itibarla stratejik yönlülük, işletmelerin hızla değişen rekabet ortamında dinamik yetenekler geliştirmesine özellikle müşteriler, rakipler ve teknoloji gibi etkileşenler ile ilişkilerinin geliştirilmesine ve yürütülmesine kaynak olmaktadır (Zhou ve Li, 2010).

Stratejik yönlülük, maliyet, müşteri ve rakip yönlülük boyutları ile tanımlanır ve işletmede paylaşılan değerlerin ve davranışların oluşturulmasını örgütün farklı düzey ve katmanlarına yayılmasını ve bir kültüre dönüşmesini destekler. Bu kültür, örgüt içinde davranış normlarını sağlayan ortak değerlerin ve inançların bir örüntüsü olarak oraya çıkar (Desphpande ve Webster, 1989). Tablo 1'de stratejik yönlülük boyutlarının açıklamaları kısaca verilmektedir. 


\section{N. Papatya - G. Papatya - B. Hamşığlu 12/4 (2020) 4051-4064}

Tablo 1: Stratejik Yönlülük Boyutları

\begin{tabular}{|c|c|}
\hline Boyutlar & Açıklama \\
\hline $\begin{array}{l}\text { Müşteri } \\
\text { Yönlülük }\end{array}$ & $\begin{array}{l}\text { Müşteri yönlülük, hedeflenen alıcıların anlaşılmasını kolaylaştıran ve müşteri değerinin sürekli oluşturulmasını } \\
\text { sağlayan bir örgüt kültürüdür. Müş̧eri yönlülüğe sahip işletmeler, hedeflenen müşterilerin mevcut ve } \\
\text { gelecekteki ihtiyaçları hakkında istihbarat oluşturur ve bu bilgiler örgüt çerisinde yayılır. Müşteri yönlü bir } \\
\text { işletme içinde çalışanlar, müşterilerin kimler olduğu ve nasıl davranmaları gerektiğini bilirler. Müşteri } \\
\text { yönlülügün iki kritik bileşeni, tedarik zinciri fırsatlarını ve kısıtlarını müşterinin bakış açısından görmeye } \\
\text { odaklanmaktır. Bu işletmenin potansiyel yeni müşterileri için değer yaratma fırsatları ile birlikte tanımlanmasını } \\
\text { sağlar. }\end{array}$ \\
\hline $\begin{array}{l}\text { Rakip } \\
\text { Yönlülük }\end{array}$ & $\begin{array}{l}\text { Rakip yönlülük, mevcut ve potansiyel kilit rakiplerini kısa vadeli güçlü ve zayıf yönlerini ve uzun vadeli } \\
\text { yeteneklerini ve stratejilerini anlamalarını vurgulayan bir örgüt kültürüdür. Rakip yönlülüğü benimseyen } \\
\text { işletmeler, hedeflenen rakiplerin ve potansiyel rakipleri derinlemesine değerlendirerek elde edilen bilgiyi } \\
\text { rakiplerin güçlü yanları ile eşleştirmek ya da onları geçmek için kullanır. Rekabet yönlü bir işletmede rekabetçi } \\
\text { değerlendirmeler sadece üstü yönetimin sorumluluğunda değildir. İşletmede çalışanlar, rakiplerin yeni ürünleri } \\
\text { ve hizmetlerle ilgili olarak pazar istihbaratı geliştirmenin yanı sıra doğrudan rakip olarak kabul edilmeyen } \\
\text { işletmelerin sunduğu ürün ve hizmetleri de takip ederler. }\end{array}$ \\
\hline $\begin{array}{l}\text { Maliyet } \\
\text { Yönlülük }\end{array}$ & $\begin{array}{l}\text { Maliyet yönlülük, bir işletmenin değer zincirinin tüm bölümleri boyunca verimlilik arayışını ifade eder. Maliyet } \\
\text { yönlülüğün odak noktası içsel olduğu için müşteri ve rakip yönlülükten farklıdır. Maliyet yönlü bir işletme } \\
\text { pazara ürün ve hizmet sağlama maliyetleri ile ilgili derinlemesine bilgi birikimine büyük önem vermektedir. } \\
\text { Ortalama ve marjinal maliyetlerin düşürülmesi, bu tür bir stratejik yönlülüğün tipi faydalarıdır. Ürün ve hizmet } \\
\text { sunumlarını gelişimi ile ilişkili maliyetlerin azaltılmasında aktif olarak faaliyet gösteren işletmeler, potansiyel } \\
\text { müşteriler için cazip fiyatlandırma veya ek özellikler sunabildikleri için yeni iş alanlarında rekabet avantajı elde } \\
\text { ederler. }\end{array}$ \\
\hline
\end{tabular}

Kaynak: Tablo Narver ve Slater, 1990; Kohli ve Jaworski, 1990; Dickson, 1992; Deshpande vd., 1993; Porter, 1998; Olson vd., 2005'den yararlanılarak hazırlanmıştır.

Temelde stratejik yönlülük boyutları işletme stratejik davranışlarına ve işletme hedeflerine bağlı gerçekleşir. Sözgelimi, işletme müşteri yönlülükte müşteri değeri yaratma, rakip yönlülükte rakipleri yakından izleme, maliyet yönlülükte ise değer zinciri verimliliği hedeflenir. Ancak her halde işletmelerin birden fazla stratejik davranış kümesini seçebilirliği ve uygulayabilirliği söz konusudur (Day, 1990; Gatignon ve Xuereb, 1997; Porter, 1998; Olson vd., 2005).

\subsection{Hizmet Yenilik}

Yenilikle ilgili alan yazının çoğu ürün yeniliğine odaklanır. Hizmet yeniliği ise, kavramsal olarak incelenmiş ve üzerine çok az ampirik çalışma yapılmıştır (Damanpour, 1991). Rogers (1983)'in yaptığı çalışmada yenilik, bir birey veya kuruluş tarafından yeni olarak algılanan bir fikir, uygulama veya nesne olarak tanımlanır (Rogers, 1983: 11). İlk bakışta bu tanımın hizmet yeniliği kapsamında değerlendirme yönü varsa da, hizmet yeniliği için daha özgül bir tanımın yapılması ihtiyaç vardır.

Hizmet yeniliği, belli bir hedef kitleye yeni ve faydalı olarak algılanan yeni bir hizmetin geliştirilmesidir (Flint vd., 2005). Hizmet geliştirme müşteriler kadar işletmelere de değer katar. Bu durumda "hizmete dayalı rekabet" kapsamında düşünülür. Sözgelimi işletmeler lojistik hizmetleri dağıtımda daha fazla hız, güvenilirlik, esneklik ve maliyet etkinliği göstererek, rekabet avantajı sağlama yolu araştırılır (Daugherty vd., 1998; Richey vd., 2004; Sinkovics ve Roath, 2004).

Hizmet yeniliği, özelde hizmet işletmelerin ayrılmaz bir parçası olarak, müşterinin/ürünün özelliklerine, hizmet yenilik performansına ve kullanım sonuçlarına dönük müşteri değeri yaratmak ile ilgilidir. Bu nedenle işletmeler müşteriye üstün değer yaratan yeni hizmetler geliştirirken, çevresel değişimleri yakından izler. Çevresel değişimde edinilen istihbarat işletme rekabetini desteklemek açısından önemsenir (Woodruff, 1997; Flint ve Mentzer, 2000; Kandampully, 2002; Benner ve Tushman, 2002).

\subsection{Pazar Performans1}

Stratejik yönlülük (boyutları) ve yenilik sıklıkla üstün pazar performans sonucu olarak kavramsallaştırılır (Papatya, 2006a). Alan araştırmacıları, pazar yönlü bir felsefenin sonucu olarak stratejik yönlülük (boyutları) ve hizmet yeniliği arasında bir ilişki olduğunu, pazar ortamında olaylarla yüzleşmesi ve buna tepki verme niyetinin araştırılması gerektiğini belirtirler. Bu halde işletmenin doğrudan kâr elde etme ve rekabet etme yeteneği olacağını ileri sürerler (Kohli ve Jaworski, 1990; Narver ve Slater, 1990; Day, 1994; Harrison-Walker, 2001). 


\section{N. Papatya - G. Papatya - B. Hamşığlu 12/4 (2020) 4051-4064}

Pazar performansı, işletmenin önceden belirlediği veya sonradan düzenlediği belirli amaçları gerçekleştirmek üzere rekabetçi stratejilerini, kaynaklarını ve yeteneklerini uyum içinde hareketliliği yaratma ve hareketlilikle elde edilen sonuçlar veya uygulama avantajları sağlama şeklinde ifade edilir. Aynı zamanda pazar performansı işletmenin değer yaratma yeteneğini gösterir ve pazar payı ve satış hacmi gibi unsurları içerir (Halit, vd., 2016). Daha yalın olarak pazar performansı, örgütsel hedeflerin gerçekleştirilmesinde pazar payındaki artış, kârlılık ve satış odaklı tanımlanır (Eren, vd., 2013). Ancak pazar performansı ölçütlerinde ve ölçümlerinde yeknesaklık bulunmaz.

Alan yazın incelendiğinde, farklı araştırmacıların faklı pazar performans ölçütleri ve ölçümleri ile ilgilendikleri görülmektedir. Makalede pazar performans ölçütleri ve ölçümleri, stratejik yönlülük boyutlarının hizmet yetenek yeniliği ilişkisine bağlı ortaya çıkan bir sonuç olarak izlenmektedir. Sözgelimi yenilikçilik performansı, üretim, finansal, pazar ve finansal performans gibi farklı çalışmaların konusu olarak ele alınır (Venkatraman ve Ramanujam, 1986; Ferdows ve De Meyer, 1990; Calantone, 2002; Hooley, vd., 2005).

\section{Kuramsal Çerçeve ve Hipotezlerin Geliştirilmesi}

Bir işletmenin benzersiz kaynakların ve yeteneklerin etkin kullanımı rekabet avantajı ve pazar performansı sağlar (Barney, 1991). Bu yönde "Kaynak Tabanlı Görüş", araştırmanın temel kuramsal çerçevesini oluşturur (konu ile ilgili Türkiye'de yapılan ilk kapsamlı çalışma için Papatya, 2002; Papatya, 2003). Bu amaçla işletme kaynakları, yetenekleri ve pazar performansı arasında pozitif ilişkiyi gösteren çalışmalar mevcuttur (Closs ve Xy, 2000; Autry vd., 2005).

Kaynaklar genellikle işletme performansı için, stratejilerin geliştirilmesini ve uygulamaya aktarılmasını sağlayan, varlıklar, süreçler, yetenekler, bilgiler vb. gibi fiziki veya fiziki olmayan kaynaklar olarak tanımlanır (Barney, 1991; Grant, 1991). Kaynaklar somut veya soyut olabilir. Makale temel konusu stratejik yönlülük boyutları (müşteri yönlülük, rakip yönlülük ve maliyet yönlülük) da, örgütsel kültür kaynakları olarak işletme yetenekleri kapsamını oluşturur (Grant, 1991). İşletme yetenekleri, işletmenin girdileri çıtılara dönüştürmesini belirleyen karmaşık rutinleri niteler (Collis, 1994). Hizmet yeniliği de bu araştırmada ele alınan bir yetenek olarak tanımlanır.

Yanı sıra işletmeler müşteri değerini yaratması ve sürdürmesi sonucunda rekabet avantajı sağlar. Pazar bilgisi stratejik yönlülügün öne çıkan unsurudur. İşletmenin rekabet avantajı elde etme yeteneği, büyük ölçüde işletme pazar bilgisini çepçevre okuma becerisinden veya rekabet zekâsının benzersizliğine bağlıdır (Zander ve Kogut, 1995; Grant, 1996; Papatya, 2006b; Papatya ve Papatya, 2007; Turner ve Makhija, 2006).

Müşteri yönlülük, müşteri ihtiyaç ve değerlerinin işletme içinde bölümler ve yöneticiler ve işletmenin tüm çalışanları arasında biçimsel olarak iletilen bir kültürdür. Burada iletişim alışverişi örgütsel yeteneklerin gelişimini destekler. Sonuçta işletme ihtiyaçlarındaki değişiklikleri öngörmek ve yeni ürün ve hizmetler geliştirmek için doğru konumlandırılma hedeflenir. Bu yönde yapılan araştırmalarda hizmet yeniliğinin müşteri beklentilerinin ötesinde bir sonuç elde etmek için, bir işletmenin müşteri adına düşünmeye odaklanma yeteneğinden kaynaklanabileceğini ileri sürülür (Day, 1994; Teece, 1998; Kandampully, 2002). Bu bağlamda oluşturulan makale araştırma hipotezi şu şekildedir:

\section{H1: Müşteri yönlülük ile hizmet yenilik yeteneği arasında pozitif bir ilişki vardır.}

Rakip yönlülüğe sahip olan işletmeler mevcut ve potansiyel rakip zekâları ile ilgilidir. Rekabetin varlığı ve tehdidi, yenilikçi hizmet sunumları ve kaynağını daha verimli kullanılması için bir itici güçtür. Rakiplerin güçlü yönlerini tanımlamak için bir işletmenin çalışanları arasında rekabetçi zekânın işlek hale gelmesi önemlidir. Çünkü rekabetçi zekânın işlemesi yenilik doğurur.

Bir işletmenin hizmet yenilik yeteneği büyük ölçüde bir bilgi tabanının gelişmişliğine bağlı olsa da, rakip yönlü bir kültüre ve rakipler ile ilgili bilgi toplayarak hizmet yeniliğinin geliştirilmesine katkıda bulunmaktadır (Dickson, 1992; Hunt ve Morgan, 1996; Han ve Sirivastava, 1998; Olson vd., 2005). Bu bağlamda oluşturulan makale araştırma hipotezi şu şekildedir:

H2: Rakip yönlülük ile hizmet yenilik yeteneği arasında pozitif bir ilişki vardır.

Maliyet yönlülük örgütün maliyet azaltma talebidir. Yapılan araştırmalar maliyet yöneliminin maliyeti düşürme ve artırılmış performans ile süreç iyileştirmesine katkıda bulunabileceğini gösterir. Daha açık olarak maliyet yönlülük işletmenin maliyetleri azaltma, süreç ve hizmet sunum yenilikleri uygulaması ve teşvik 


\section{N. Papatya - G. Papatya - B. Hamşığlu 12/4 (2020) 4051-4064}

etmesidir. Her ne kadar yapılan maliyet yönlü yeniliklerin rakip işletmelerce taklit edilmesi zor olsa da, daha cazip görülebilir; bu da maliyet yönlülüğün farklı yetenekleri geliştirebileceğini düşündürür (Dickson, 1992; Ledered ve Rhee, 1995; He ve Wong, 2004; Yasin vd., 2005). Bu bağlamda oluşturulan makale araştırma hipotezi şu şekildedir:

\section{H3: Maliyet yönlülük ile hizmet yenilik yeteneği arasında pozitif bir ilişki vardır.}

Yenilik yeteneği işletme pazar performansını olumlu yönde etkiler. Hizmet yeniliklerinin işletmelere faydası, yeni bir yol ve mevcut ürünlere yeni bir soluk getirmesidir. Bu işletmenin mevcut ürünlerle ilgili yeni bir hizmet sunarak yapılmasını işaret eder. Hizmet yeniliklerinin katma değeri bir işletmenin yeni pazarlara girmesine ve yeni müşterilere ulaşmasına izin verir. Tamamen yeni hizmetlerin geliştirilmesi işletmelerin yeni pazar bölümlerine ulaşmasını sağlar. Yenilik yetenekleri geliştiren işletmeler pazar liderliğini yakalayabilir (Persson, 1991; Hult vd., 2004; Keskin, 2006;). Bu bağlamda oluşturulan makale araştırma hipotezi şu şekildedir:

\section{H4: Hizmet yenilik yeteneği ile işletmenin pazar performansı arasında pozitif bir iliş̧ki vardır.}

Makale araştırma modeli ve kavramsal/kuramsal çerçeve tanımlarına ve notlarına bağlı oluşturulan hipotezler Şekil 1'de sunulmaktadır. Makale araştırma modeli, değişkenler arasında bir neden sonuç ilişkisi olduğu için bir nedensellik modeli şeklinde düzenlenmiştir (Malhotra, 2007).

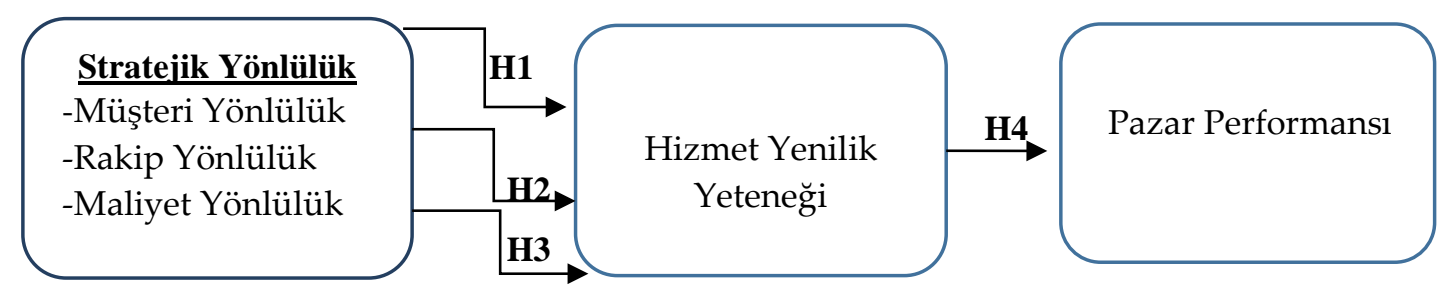

Şekil 1: Makale Araştırma Modeli ve Hipotezler

\section{Yöntem}

\subsection{Veri Toplama}

Araştırmanın ana kütlesi Antalya ilinde faaliyet gösteren ve Ticaret ve Sanayi Bakanlığı́na kayıtlı 879 işletme oluşturmaktadır. Bu amaçla Antalya ilinin farklı semtlerinde ve ilçelerindeki üretim işletmelerinin tamamı ile iletişime geçilerek işletme yöneticilerine araştırma kapsamı anlatılmış ve araştırmaya katılmayı kabul eden 180 işletme ile görüşülerek araştırma gerçekleştirilmiştir. Çalışma Mayıs-Eylül 2019 ayları arasında anketörler yardımı ile gerçekleştirilmiş ve çalışmada kolayda örnekleme yöntemi kullanılmıştır.

\section{2 Ölçekler}

Araştırmada kullanılan ölçek, $1=$ kesinlikle katılmıyorum ve $5=$ kesinlikle katılıyorum şeklinde 5 'li likert tipi ölçektir. Müşteri yönlülük ölçeği, Deshpande ve Farley (1998) de yapılan çalışmadan yararlanılarak 5 madde ile ölçülmüştür. Rakip yönlülük ölçeği, Narver ve Slater (1990) ve Olson ve arkadaşlarının (2005) yılında yaptıkları çalışmadan yararlanılarak 5 madde ile ölçülmüştür. Maliyet yönlülük ölçeği, Olson ve arkdaşlarının (2005) ve Homburg ve arkdaşlarının (1999) yılında yapılan çalışmadan yararlanılarak 5 madde ile ölçülmüştür. Hizmet yenilik yeteneği ölçeği Grawe ve arkadaşlarının (2009) yılında yapılan çalışmadan yararlanılarak 5 madde ile ölçülmüştür. Pazar performansı da Claycomb ve arkadaşlarının (1999) ve Jaworski ve Kohli (1993) de yaptıkları çalışmadan yararlanılarak 4 madde ile ölçülmüştür.

\subsection{Analiz Yöntemi}

Araştırma Partial Least Squres (PLS) kısmi en küçük kareler yöntemi kullanılarak model testi uygulanmıştır. PLS yöntemi, varyans tabanlı yapısal eşitlik modellemesi (SEM), araştırmalarda yapılar arasındaki neden sonuç ilişkilerini tahmin etmek için kullanılan ikinci nesil çok değişkenli istatistiksel bir teknik olarak uygulanmıştır (Henseler vd., 2016). 


\subsection{1 Ölçüm Modeli}

PLS analizinde ilk önce ölçüm modelinin geçerliliği ve güvenilirliği test edilmiştir. Alfa katsayısına bakılarak modeldeki yapıların iç tutarlılığı değerlendirilmiştir. Bunun için alfa katsayısının 0.70 eşik değerinden yüksek olması gerekmektedir. PLS analizinde alfa katsayısına bakmak yeterli olmamaktadır. Alfa katsayısı yerine (Composite Reliability-CR) bileşik güvenilirlik katsayısına bakılması önerilmektedir. Bileşik güvenilirlik katsayısının 0.70 ve üzerinde olmasının gerektiği belirtilmiştir (Bagozzi ve Yi, 1988; Wong, 2013). Tablo 2' de modeldeki yapıların alfa ve bileşik güvenilirlik katsayıları gösterilmektedir.

Tablo 2: Yapı Güvenilirliği Sonuçları

\begin{tabular}{|l|c|c|}
\hline Yapılar & Cronbachs Alfa $(\alpha)$ & Composite Reliability \\
\hline Müşteri Yönlülük & 0.86 & 0.90 \\
\hline Rakip Yönlülük & 0.90 & 0.93 \\
\hline Maliyet Yönlülük & 0.91 & 0.93 \\
\hline Hizmet Yenilik Yeteneği & 0.92 & 0.94 \\
\hline Pazar Performansı & 0.88 & 0.92 \\
\hline
\end{tabular}

Tablo 2'de görüldüğü gibi yapıların tamamı belirtilen eşik değerlerinin üzerinde ve ölçüm modelinin içsel tutarlılığı ve bütünsel güvenilirliğe sahip olduğu görülmüştür. Daha sonra çalışmada, yakınsaklık ve ayırma geçerliliğini test edilmiştir. Bunun içinde her bir boyutun ortalama varyans değerleri (AVE) değerlerine bakılmıştır. AVE değerinin 0.50 'den büyük olması durumunda yakınsaklık geçerliliğinin sağlandığı kabul edilir (Fornell ve Lacker, 1981). Tablo 3'de ortalama varyans değerleri (AVE) değerleri gösterilmektedir.

Tablo 3: Ortalama Varyans Değerleri (AVE) Sonuçları

\begin{tabular}{|l|c|}
\hline Yapılar & AVE \\
\hline Müşteri Yönlülük & 0.64 \\
\hline Rakip Yönlülük & 0.72 \\
\hline Maliyet Yönlülük & 0.74 \\
\hline Hizmet Yenilik Yeteneği & 0.76 \\
\hline Pazar Performansı & 0.74 \\
\hline
\end{tabular}

Tablo 3 incelendiğinde yapıların hepsinde AVE değerlerinin 0.50'den yüksek olduğu görülmektedir. Daha sonra ise ayırma geçerliliğine bakılmıştır. Ayırma geçerliliği içinde her bir yapının AVE'nin karekökünün yapılar arasındaki korelasyonlardan daha büyük olması beklenir (Fornell ve Lacker, 1981). Ayırma geçerliliği sonuçları Tablo 4'de gösterilmektedir.

Tablo 4: Ayrışma Geçerliliği Sonuçları

\begin{tabular}{|l|c|c|c|c|c|}
\hline & $\begin{array}{c}\text { Müşteri } \\
\text { Yönlülük }\end{array}$ & $\begin{array}{c}\text { Rekabet } \\
\text { Yönlülük }\end{array}$ & $\begin{array}{l}\text { Maliyet } \\
\text { Yönlülük }\end{array}$ & $\begin{array}{l}\text { Hizmet } \\
\text { Yenilik } \\
\text { Yeteneği }\end{array}$ & Pazar Performans1 \\
\hline Müşteri Yönlülük & $\mathbf{0 . 8}$ & & & & \\
\hline Rakip Yönlülük & 0.72 & $\mathbf{0 . 8 5}$ & & & \\
\hline Maliyet Yönlülük & 0.68 & 0.79 & $\mathbf{0 . 8 6}$ & & \\
\hline Hizmet Yenilik Yeteneği & 0.61 & 0.77 & 0.73 & $\mathbf{0 . 8 7}$ & \\
\hline Pazar Performansı & 0.58 & 0.65 & 0.70 & 0.74 & $\mathbf{0 . 8 6}$ \\
\hline
\end{tabular}

Tablo 4'de yapılar arasındaki korelasyonları göstermektedir. Koyu yazılı değerler AVE değerlerinin karekökünü göstermektedir. Tablo 4 incelendiğinde AVE değerlerinin karekökü yapılar arasındaki korelasyon değerlerinden büyük olduğu izlenmiştir (Fornell ve Lacker, 1981; Wong, 2013). 


\subsubsection{Yapisal Model}

Ölçüm modeli incelendikten sonra yapısal modeli ve hipotezleri test etmek için modeldeki yol katsayılarının gerçek değerinin hesaplanması için yeniden örnekleme yöntemi olan Bootstrapping yapılmıştır. Minimum Bootstrapping sayısı 5000 olmalıdır. Bootstrapping yardımı ile iç ve dış modeller için anlamlı $t$ değerleri üretilir (Hair, vd., 2011; Wong, 2013). Bu araştırmada, Bootstrapping yöntemi kullanılarak örneklem sayısı 5000 çıkarılmıştır. İçsel modele ait $t$ değerleri Tablo 5'de gösterilmiştir.

Tablo 5: İçsel Modele Ait Yol Katsayılarının t-Değerleri

\begin{tabular}{|l|c|c|}
\hline & t-İstatistiği & p değeri \\
\hline Müşteri Yönlülük $\rightarrow$ Hizmet Yenilik Yeteneği & 3.350 & $\mathbf{0 . 0 0 1}$ \\
\hline RakipYönlülük $\rightarrow$ Hizmet Yenilik Yeteneği & 2.835 & $\mathbf{0 . 0 0 5}$ \\
\hline Maliyet Yönlülük $\rightarrow$ Hizmet Yenilik Yeteneği & 2.930 & $\mathbf{0 . 0 0 0}$ \\
\hline Hizmet Yenilik Yeteneği $\rightarrow$ Pazar Performansi & 35.354 & $\mathbf{0 . 0 0 0}$ \\
\hline
\end{tabular}

Tablo 5'de t değerleri 2.58' den büyük için \%99 düzeyinde anlamlıdır. Daha sonra ise dış modelin $t$ değerlerini incelemek gerekmektedir. Dış modelin t değeri Tablo 6'da gösterilmektedir.

Tablo 6'da görüldüğü gibi t değerlerinin hepsi 2.58'dan büyük olduğu için \%99 düzeyinde yol katsayıları anlamlıdır. Daha sonra yapısal modelde analizin bir parçası olan determinasyon katsayısı $\left(R^{2}\right)$ değerlendirmesine geçilir. Hizmet yenilik yeteneği, $R^{2}$ değeri 0.85 ve pazar performansı 0.77 olduğu görülmüştür. Bu duruma göre, yol kat sayılarının önem seviyelerine bakıldığında elde edilen bulguların tamamı kuramsal çerçevede de oluşturulan araştırma modelini destekler niteliktedir. Yazında $\mathrm{R}^{2}$ değerleri 0.75, 0.50 ve 0.25 olarak önemli, orta ve zayıf olarak tanımlanmaktadır (Hair vd., 2011; Hair vd., 2014).

Tablo 6: Dışsal Modele Ait Yol Katsayılarının t-Değerleri

\begin{tabular}{|c|c|c|c|c|c|c|}
\hline & $\begin{array}{c}\text { Müşteri } \\
\text { Yönlülülk }\end{array}$ & $\begin{array}{c}\text { Maliyet } \\
\text { Yönlülük }\end{array}$ & $\begin{array}{l}\text { Rakip } \\
\text { Yönlülük }\end{array}$ & $\begin{array}{l}\text { Hizmet } \\
\text { Yenilik } \\
\text { Yeteneği }\end{array}$ & $\begin{array}{l}\text { Pazar } \\
\text { Performans1 }\end{array}$ & p değeri \\
\hline MUY1 & 20.525 & & & & & 0.000 \\
\hline MUY2 & 28.848 & & & & & 0.000 \\
\hline MUY3 & 65.568 & & & & & 0.000 \\
\hline MUY4 & 18.144 & & & & & 0.000 \\
\hline MUY5 & 22.180 & & & & & 0.000 \\
\hline MALY1 & & 35.775 & & & & 0.000 \\
\hline MALY2 & & 31.962 & & & & 0.000 \\
\hline MALY3 & & 51.132 & & & & 0.000 \\
\hline MALY4 & & 34.554 & & & & 0.000 \\
\hline MALY5 & & 25.446 & & & & 0.000 \\
\hline RAY1 & & & 40.594 & & & 0.000 \\
\hline RAY2 & & & 38.492 & & & 0.000 \\
\hline RAY3 & & & 19.814 & & & 0.000 \\
\hline RAY4 & & & 32.240 & & & 0.000 \\
\hline RAY5 & & & 34.882 & & & 0.000 \\
\hline HIZY1 & & & & 29.207 & & 0.000 \\
\hline HIZY2 & & & & 37.465 & & 0.000 \\
\hline HIZY3 & & & & 35.637 & & 0.000 \\
\hline HIZY4 & & & & 34.477 & & 0.000 \\
\hline HIZY5 & & & & 74.762 & & 0.000 \\
\hline PAZP1 & & & & & 29.980 & 0.000 \\
\hline PAZP2 & & & & & 37.297 & 0.000 \\
\hline PAZP3 & & & & & 47.337 & 0.000 \\
\hline PAZP4 & & & & & 45.712 & 0.000 \\
\hline
\end{tabular}

Sonuç olarak araştırma bulguları göstermektedir ki; $\mathrm{R}^{2}$ değerlerinin yüksek düzeyde olduğu görülmüş ve hipotez geliştirme aşamasında oluşturulan araştırma hipotezleri $H 1$, H2, H3 ve H4 kabul edilerek oluşturulan model tam olarak doğrulanmıştır. Tablo 7'de özet hipotez kabul tablosu görülmektedir. 
N. Papatya - G. Papatya - B. Hamşığlu 12/4 (2020) 4051-4064

- Araştırmada müşteri yönlülük, hizmet yenilik yeteneğini $(\gamma 1=0.237, \mathrm{t}=3.350, \mathrm{p}=0,001)$, doğrudan ve pozitif olarak etkilediği görülmüştür. H1 hipotezi kabul edilmiştir.

- Rakip yönlülük hizmet yenilik yeteneğini $(\gamma 2=0.524, \mathrm{t}=2.835, \mathrm{p}=0,005)$, doğrudan ve pozitif olarak etkilediği görülmüş ve $H 2$ hipotezleri kabul edilmiştir.

- Araştırmada maliyet yönlülük hizmet yenilik yeteneğini $(\gamma 3=0.460, \mathrm{t}=2.930, \mathrm{p}=0,000)$, doğrudan ve pozitif olarak etkilediği görülmüştür. H3 hipotezi kabul edilmiştir.

- Araştırmada hizmet yenilik yeteneği pazar performansını $(\gamma 4=0.878, t=35.354, p=0,000)$, doğrudan ve pozitif olarak etkilediği görülmüştür. Oluşturulan H4 hipotezi kabul edilmiştir.

Tablo 7: Hipotezlerin ve Sonuçların Özeti

\begin{tabular}{|l|c|}
\hline \multicolumn{1}{|c|}{ Hipotezler } & Sonuç \\
\hline H1: Müşteri yönlülük ile hizmet yenilik yeteneği arasında pozitif bir ilişki vardır & Kabul \\
\hline H2: Rakip yönlülükk ile hizmet yenilik yeteneği arasında pozitif bir ilişki vardır & Kabul \\
\hline H3: Maliyet yönlülük ile hizmet yenilik yeteneği arasında pozitif bir ilişki vardır & Kabul \\
\hline H4: Hizmet yenilik yeteneği ile işletmenin pazar performansı arasında pozitif bir ilişki vardır & Kabul \\
\hline
\end{tabular}

Oluşturulan PLS yapısal modeli Şekil 2'de gösterilmektedir.

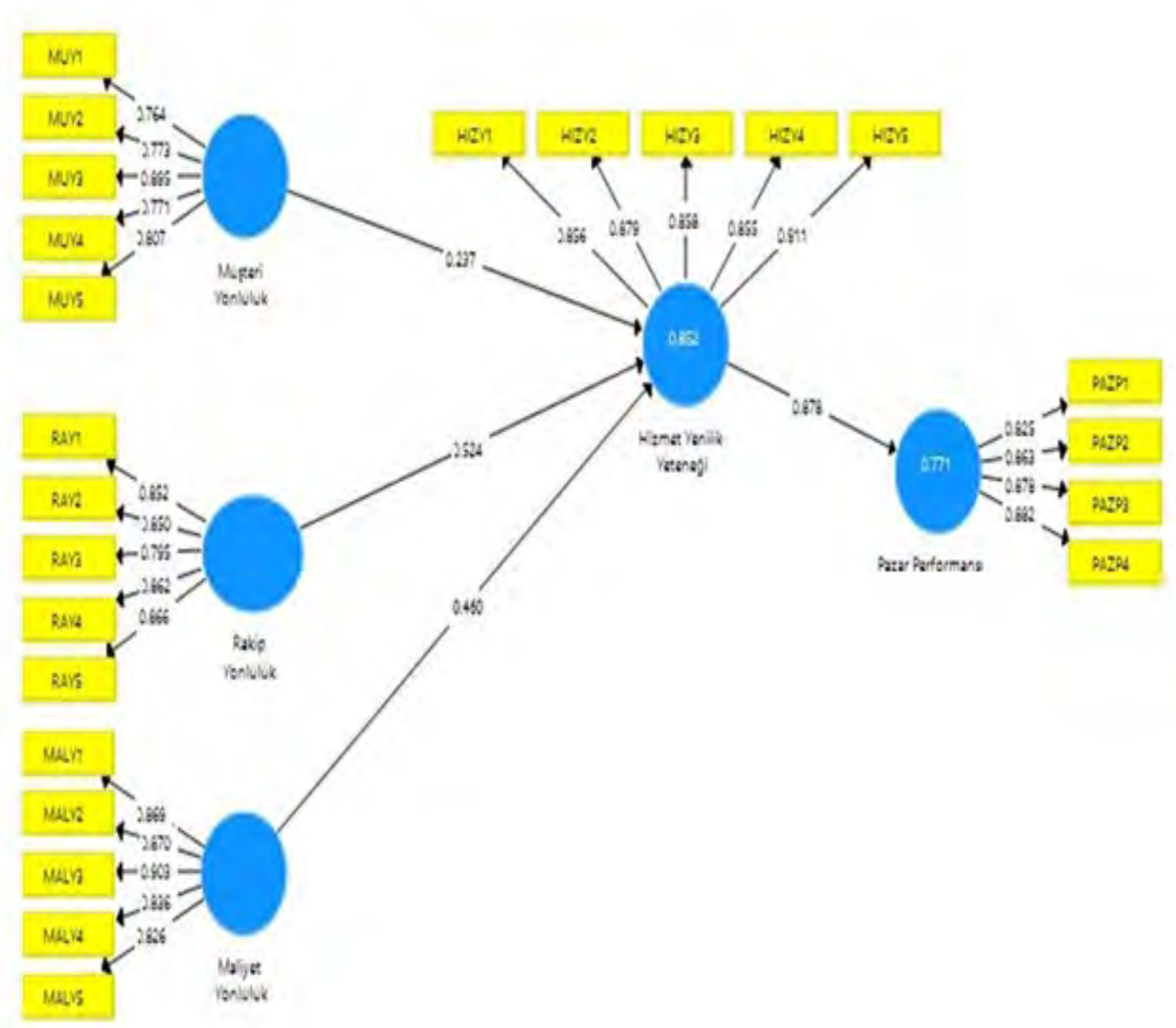

Şekil 2: PLS Yapısal Model 


\section{Sonuç ve Tartışma}

Bu makalede stratejik yönlülük boyutları, Türkiye ve Antalya ili özelinde ampirik olarak incelemiştir. Elde edilen bulgulara göre stratejik yönlülük boyutlarının işletme hizmet yenilik yeteneğine ve hizmet yenilik yeteneklerinin pazar performansı üzerinde farklı etkiler yarattığı görülmüştür.

Temelde hizmet yenilik yeteneğini güçlendirerek ürünleri yeniden konumlandırmak, işletmelerin rekabet avantajı elde etmelerine yardımcı olma yönü yüksektir. Ancak, Flint vd. (2005) yapmış olduğu araştırma makalesi dışında bu argümanları destekleyecek çok az ampirik veri bulunmaktadır. Muhtemeldir ki, bu makale ile hizmet yenilik yeteneğini ölçümünde, hizmet yenilik yeteneği ve performans ilişkisini saptamaya yönelik (H4 hipotezi) ampirik katkıda bulunma kapasitesi bir nebze zorlanmış olmaktadır.

Makalede, örgüt kültürünün işletme hizmet yenilik yeteneğini artıracağı önermesi öncelenebilir. Bu yönde önceden yapılan araştırma makalelerinde, örgüt kültürünün işletme stratejik yönlülüğüne etkisi (Narver ve Slater, 1990; Desphande vd., 1993; Hurley ve Hult, 1998), bu makale ile müşteri yönlülük, rakip yönlülük ve maliyet yönlülük olarak boyutları ile ampirik incelenmesi sağlanmıştır. Elde edilen sonuçlar stratejik yönlülüğün bir işletmenin hizmet yenilik yetenekleri üzerinde etkileri olduğunu göstermiştir:

H1 ve H2 sonuçlarının gösterdiği gibi, müşteri yönlülük ve rakip yönlülük her ikisinin de hizmet yenilik yetenekleri ile pozitif ilişkili olduğu görülmüştür. Bu sonuçlar, Han vd. (1998) yaptığı araştırmada, müşteri yönlülük ve rakip yönlülük bir işletmenin yenilikçiliği artıracağı argümanına benzerdir. Müşteri ve rakip yönlülük dışarıya odaklanmaktadır. Dış çevre ve pazar taleplerini anlamaya ve bunlara cevap vermeye yardımcı olmak için bilgiye ihtiyaç duymaktadır. Bu bilgiler pazar boşlukları, yeni fırsatlar vb. kapsamları tespit etmeye yardımcı olur ve aynı zamanda hizmet geliştirme sürecinde de kullanılabilirliği söz konusudur. Bu durum işletmenin tedarik zinciri bağlamında hizmet sunumunda yenilikçi olması, işletmenin güçlü şekilde dışa odaklanmasını sağlar. Dolayısıyla işletmenin özellikle, müşterilerin ilgisine odaklanmak, toplam müşteri memnuniyeti arayışını destekleme ve sürekli yeniliği teşvik edeceği düşünülebilir (Peters, 1984). O halde pazarlama kavramının önerdiği uzun vadeli yönelim ile de tutarlık izlenebilir. Yani uzun vadeli yönelimle müşteri yönlülük, işletmenin stratejik kararlar ile daha çok ilgilenmesi gerektiği söylenebilir (Han vd., 1998).

Bir işletmenin müşteri yönlülüğü, rakip yönlülüğü engellemez. Çünkü müşteri yönlülük -rakiplere yönelme de dâhil olmak üzere- dengeli bir yaklaşım ve işletme ortamında daha kapsamlı bir görünüm sağlar. Bu sayede özellikle rakipleri bir referans olarak kullanan rakip yönlü işletmeler, kendi güçlü ve zayıf yönleri belirleme ve bir adım önde olmak için yenilikçi hizmet önerileri geliştirme olanağı sağlamış olur.

H3 sonucuna göre, maliyet yönlülük hizmet yenilik yeteneğini pozitif etkilediği görülmüştür. Müşteri ve rakip yönlülükle kıyaslandığında maliyet yönlülük, içsel odaklıdır. Rekabetçi zekâ (pazar istihbaratı) ile dış bilgilerinin işlenmesi, hizmet yenilik yeteneğinin yaratılmasına etki etmektedir. Ancak elde edilen bilgilerin gerçekçi olup olmadığını görmek için gerçek maliyetlerin göz önüne alınması gerekir. Yine de işletmelerin maliyeti düşürmek için ürünlerde veya süreçlerde potansiyel olarak iyileştirmeler veya değişiklikler yapması mümkündür. $\mathrm{O}$ halde hizmet yenilik yeteneklerinin artırılması, ürünlerin yeniden konumlandırılmasını sağladığı ve işletme rekabet avantajını artırdığı söylenebilir.

Öte yandan işletmelerde maliyet yönlülük, ürün yeniliği veya süreç yeniliği gibi diğer yenilik türleri için de önemli bir motivasyon olabilir. İşletmeler, maliyeti düşürmek için ürünlerde veya süreçlerde potansiyel iyileştirme veya değişiklikleri gerçekleştirebilir. Ayrıca, maliyet yönlülükten kaynaklanan süreç yeniliği, hizmet alanındaki yeniliklere de katkıda bulunabilir. Sonuçta makale, maliyet yönlülüğün hizmet yenilik yeteneğinin doğrudan bir itici gücü olduğunu öne sürse de, maliyet yönlülüğün rolünü keşfetmek için daha fazla araştırmaların yapılmasını gerekmektedir.

\section{Gelecek Araştırmalar için Öneriler}

Hizmet yenilik yeteneğini ampirik olarak incelemeye yönelik yapılan bu makale -yukarıda tartışıldığı gibibazı önemli sonuçlar sunmaktadır. Ancak makale sınırlılıklarının zorlanmasına ve hizmet yenilik yeteneğini geliştirmek ve ilerletmek için gelecekte yapılacak araştırmalara ihtiyaç olduğu açıtır. Yine de şu noktalarda öneriler sıralanabilir:

İlk olarak, stratejik yönlülük boyutları birbirini dışlamaz. Bu nedenle, her birinin muhtemel değerini araştırmak için daha çok araştırma yapmaya ihtiyaç bulunmaktadır. Genellikle işletmeler birden çok stratejik 


\section{N. Papatya - G. Papatya - B. Hamşığlu 12/4 (2020) 4051-4064}

yönlülük boyutları tarafından yönlendirilir ve birden çok davranışta bulunabilir. Ancak şu var: Herhangi bir özel yönlülük potansiyel olarak işletme için olumlu sonuçlar üretirken, farklı yönelimler farklı yönlere yol açabilir. Bu durum etkili bir şekilde yönetilmezse, en uygun sonuçlar elde edilemez.

İkinci olarak, mevcut makale hizmet yenilik yeteneklerine odaklanırken, gelecekte yapılacak çalışmalar yenilik yeteneği ile ürün yenilik yetenekleri gibi diğer yenilik yetenekleri arasındaki farkları keşfetmeye yönelik izlenebilir. Hizmetler, soyutluk ve çabuk bozulma gibi temel özellikleri nedeniyle benzersizlik gösterir. Doğal olarak hizmet yenilik yeteneklerini geliştirme süreci, diğer yenilik yeteneklerinden önemli ölçüde farklı olabilmektedir. Bu yüzden potansiyel farklılıkları anlamak, yöneticilerin uygun yönlülük seçimleri, yenilik yeteneklerinin etkin gelişimini kolaylaştırmak için kaynakları daha iyi tahsis etmelerine yardımcı olacağı söylenebilir.

Dahası, hizmet yeniliğinin oldukça geniş bir kavram olduğu ve farklı alanları ve düzeyleri kapsayabileceği göz ardı edilemez. Sözgelimi, bazı hizmet yenilikleri mevcut hizmet sunumlarını geliştirmeyi hedeflerken, diğerleri yeni hizmetleri hedefleyebilir. Ancak bu makalenin keşifsel niteliği nedeni ile sadece genel anlamda hizmet yeniliğini inceleme kapsamı, gelecekte yapılacak araştırmaların hizmet yeniliğinin daha özellikli yönlerini ayrıntılı olarak incelemesi noktasında bir başlangıç olarak düşünülebilir.

Gelecekteki araştırmalar, makalede incelenen üç stratejik yönlülüğe ek olarak, diğer potansiyel iç ve/veya dış faktörlerin hizmet yenilik yeteneğini geliştirme etkisinin araştırılması düşünülebilir. Özgül olarak bir işletmenin her bir stratejik yönlülügü geliştirmesine yol açabilecek faktörler ampirik olarak incelenmesi sağlanabilir.

Son olarak makalenin yazındaki konumu açısından şu konu vurgulanabilir: Makale alan yazında öngörülen ilişkileri ölçen az sayıda araştırmanın çoğalması noktasında katkı sağladığı düşünülebilir ve -özellikle makale uygulama sınırlılıkları ve bugünün rekabet ortamı veri kabul edilmesine bağlı- stratejik yönlülük boyutlarının hizmet yenilik yeteneklerine ve hizmet yenilik yeteneklerinin pazar performansına etkisinin daha iyi kavranması için, gelecekte konunun farklı coğrafi ölçeklerde ve sektörlerde araştırılması ve buna bağlı karşılaştırmalar yapılması ihtiyacı olduğu ifade edilebilir.

\section{KAYNAKÇA}

Alobaidi, M. and Kitapc1, O. (20199. Strategic Orientation, Market Orientation and Business Performance: In Searching for Integration, Evidence from Turkey. Montenegrin Journal of Economics, 14 (3), 53-70.

Autry, C. W., Griffis, S. E., Goldsby, T. J. and Bobbitt, L. M. (2005). Warehouse Management System: Resource Commitment Capabilities and Organizational Performance. Journal of Business Logistics, 26 (2), 165183.

Bagozzi, R. and Yi, Y. (1988). On the Evaluation of Structural Equation Models. Journal of Academy of Marketing Science, 16 (1), 74-94.

Baker, W. E. and Sinkula, J. M. (1999). The Synergistic Effect of Market Orientation and Learning Orientation on Organizational Performance. Journal of the Academy of Marketing Science, 27 (4), 411-427.

Barney, J. (1991). Firm Resources and Sustained Competitive Advantage. Journal of Management, 17 (1), 99-120.

Benner, M. J. and Tushman, M. (2002). Process Management and Technological Innovation: A Longitudinal Study of the Photography and Paint Industrial. Administrative Science Quartely, 47 (4), 676-706.

Berry, L. L., Shankar, V., Parish, J. T., Cadwallader, S. and Dozel, T. (2006). Creating New Markets through Service Innovation. Sloan Management Review, 47 (2), 56-63.

Calantone, J. R., Çavusgil, S. T. and Zhao, Y. (2002). Learning Orientation Firm Innovation Capability and Firm Performance. Industrial Marketing Management, 31, 515-524.

Chapman, R. L., Soosay, C. and Kandampully, J. (2003). Innovation in Logistics Services and the New Business Model: A Conceptual Framework. International Journal of Physical Distribution \& Logistics Management, $33(7), 630-650$. 
N. Papatya - G. Papatya - B. Hamşığlu 12/4 (2020) 4051-4064

Claycomb, C., Droge, C. and Germain, R. (1999). The Effect of Just in time with Customers on Organizational Design and Performance. International Journal of Logistics Management, 10 (1), 37-58

Closs, D. J. and Xu, K. (2000). Logistics Information Technology Practice in Manufacturing and Merchandising Firms-an International Benchmarking Study Versus World Class Logistics Firms. International Journal of Physical Distribution \& Logistics Management, 30 (10), 869-886.

Collis, D. J. (1994). Organizational Innovation: A Meta Analysis of Effect of Determinants and Moderators. Academy of Management Journal, 34 (3), 555-590.

Damanpour, F. (1991). Organizatioal Innovation: A Meta Analysis of Effects of Determinants and Moderatos. Academy of Management Journal, 34 (3), 555-590.

Damanpour, F. and Evan, W. M. (1984). Organizational Innovation and Performance: The Problem of Organizational Lag. Administrative Science Quarterly, 29 (3), 392-409.

Daugherty, P. J., Stanj, T. P. and Ellinger, A. E. (1998). Leveraging Logistics $\backslash$ Distribution Capabilities: The Effect of Logistics Service on Market Share. Journal of Business Logistics, 19 (2), 35-51.

Day, G. S. (1994). The Capabilities of Market-Driven Organizations. Journal of Marketing, 58 (4), 37-52.

Day, G. S. (1990). Market Driven Strategy. The Free Press, New York, NY.

Dehpande, R. and Webster, F. E. (1989). Organizatiponal Culture and Marketing: Defining the Reseach. Journal of Marketing, 53 (1), 3-15.

Deshpande, R. and Farley, J. U. (1998). Measuring Market Orientation: Generalization and Synthesis. Journal of Market-Focused Management, 2 (3), 213-232.

Deshpande, R., Farley, U. and Webster, F. E. (1993), Corporate Culture Customer Orientation and Innovativeness in Japanese Firms: a Quadrad Analysis. Journal of Marketing, 57 (1), 23-37.

Dickson, P. R. (1992). Toward a General theory of Competitive Rationality. Journal of Marketing, 56 (1), 69-83.

Eren, M. Ş., Tokgöz, E., Gül, H. ve Saylan, O. (2013). Pazar Odaklılığın Nitel Performans üzerindeki etkisinde Öğrenme Odaklılık ve Yenilikçiliğin Düzenleyici Etkisi. Dokuz Eylül Üniversitesi İ̈BF Dergisi, 28 (2), 139.

Ferdows, K. and De Meyer, A. (1990). Lasting Improvements in Manufacturing Performance. Journal of Operations Management, 9 (2), 168-184.

Flint, D.,J., and Mentzer, J., T. (2000). Logisticians as Marketers: Their Role when Customers' Desired Value Changes. Journal of Business Logistics, 21 (2), 19-45.

Flint, D. J., Larsson, E., Gammelgaard, B. and Mentzer, J. T. (2005). Logistics Innovation: a Customer ValueOriented Social Process. Journal of Business Logistics, 26 (1), 113-147.

Fornell, C., Lacker D. F. (1981). Evaluating Structural Equation Models with Unobservable Variables and Measurement Error. Journal of Marketing Research, 18, (1), 39-50.

Gatignon, H. and Xuereb, J. (1997). Strategic Orientation of the Firm and New Product Performance. Journal of Marketing Research, 34 (1), 77-90.

Gotteland, D., Shock, J. and Sarin, S. (2020). Strategic Orientations, Marketing Proactivity and Firm Market Performance. Industrial Marketing Management. [Basımda]

Grant, R. M. (1991). The Resource-Based theory of Competitive Advantage Implications for Strategic Formation. California Management Review, 33 (3), 114-135.

Grant, R. M. (1996). Towards A Knowledge Based theory of the Firm. Strategic Management Journal, 17, 109122.

Grawe, S., Chen, H. and Daugherty, P. (2009). The Relationship between Strategic Orientation Service Innovation and Performance. International Journal of Physical Distribution \& Logistics Management, 39 (4), 282-300. 
N. Papatya - G. Papatya - B. Hamşığlu 12/4 (2020) 4051-4064

Gronroos, C. (2015). Service Management and Marketing: Managing the Service Profit Logic, 4th Edition, John Wiley \& Sons.

Hair, J. F., Christian M. R., and Sarstedt M. (2011). PLS-SEM:Indeed A Silver Bullent. Journal of Marketing Theory and Practive, 19 (2),139-151.

Hair, J. F., Hult G. T., Ringle C. M., and Sarsted, M. (2014). A Primer on Partial Least Squares Structural Equation Modeling (PLS-SEM). Sage Publication, Thousand Oaks, California.

Hamşığlu, A. B. (2017). Girişimci Yönlülük, Stratejik Yönlülük ve Performans İlişkisi: İstanbul İli Tekstil İşletmelerinde Bir Uygulama. İşletme Araştırmaları Dergisi, 9 (2), 376-403.

Han, J. K. and Srivastava, R. K. (1998). Market Orientation and Organizational Performance: Is Innovations A Missing Link?. Journal of Marketing, 62 (4), 30-45.

Hapman, R. L., Soosay, C. and Kandampully, J. (2003). Innovation in Logistic Services and the New Business Model: A Conceptual Framework. International Journal of Physical Distibution \& Logistics Management, $33(7), 630-650$.

Harrison-Walker, J. (2001). The Measurement of a market Orientation and Its Impact on Besiness Performance. Journal of Quality Management, 6(2), 139-172.

He, Z. and Wong, P. (2004). Explorating vs. Exploitation: An Emprical test of the Ambidexterity Hypothesis. Organization Science, 15 (4), 481-494.

Henseler, J., Ringle C., and Sasted M. (2016). Testing Measurement Invariance of Composites Using Partial Least Squares. International Marketing Review, 33 (3), 405-431.

Homburg, C., Workman, J. P. and Krohmer, H. (1999). Marketing's Influence within the Firm. Journal of Marketing, 63 (2), 1-17.

Hooley, J. G., Greenley, G. E., and Cadogan, J. W. (2005). The Performance Impact of Marketing Resources. Journal of Business Research, 58 (1), 18-27.

Hult, G. T. M., Hurley, R. F. and Knight, G.,A. (2004). Innovativeness: Its Antecedents and Impact on Business Performance. Industrial Marketing Management, 33 (5), 429-438.

Hunt, S. D. and Morgan, R. M. (1996). The Resource Advantage theory of Competition: Dynamics path Dependencies and Evolutionary Dimensions. Journal of Marketing, 60 (4), 107-144.

Hurley, R. F. and Hult, G. T. M. (1998). Innovation Market Orientation and Organizational Learning an Integration and Emprical Examination. Journal of Marketing, 62 (3), 42-54.

Jaworski, B. J. and Kohli, A. K. (1993). Market Orietation: Antecedebts and Consequences. Journal of Marketing, 57 (3), 53-70.

Kandampully, J. (2002). Innovation as the Core Competency of a Service Organization: The Role of Technology Knowledge and Networks. European Journal of Innovation Management, 5 (1), 18-26.

Keskin, H. (2006). Market Orientation Learning Orientation and Innovation Capabilities in SMEs. European Journal of Innovation Management, 9 (4), 396-417.

Keskin, H., Zehir, S. ve Ayar, H. (2016). Pazar Yönelimi ve Firma Performansı İlişkisi: Farklılaştırma Stratejisinin Aracı Rolü. Doğuş Üniversitesi Dergisi, 17 (1), 111-127.

Khan, A. M. and Manopichetwattana, V. (1989). Innovation and Noninnovative Small Firms: Types and Characteristics. Management Science, 35 (5), 597-606.

Kindström, D., Kowalkowski, C. and Sandberg, E. (2013). Enabling Service Innovation: A Dynamic Capabilities Approach., Journal of Business Research, 66, 1063-1073.

Kohli, A. K. and Jaworski, B. J. (1990). Market Orientation: The Construct Reseatch Propositions and Managerial Implications. Journal of Marketing, 54 (2), 1-18. 
N. Papatya - G. Papatya - B. Hamşığlu 12/4 (2020) 4051-4064

Ledered, P. J. and Rhee, S. (1995). Economics of Total Quality Management. Journal of Operations Management, $12(3 \backslash 4), 353-367$.

Malhotra, K. N. (2007). Marketing Research An Applied Orientation. Pearson Prentice Hall.

Menguc, B. and Auh, S. (2005). A Test of Strategic Orientation formation Versus Strategic Orientation Implementations: The Influence of TMT Functional Diversity and Inter-Functional Coordination. Journal of Marketing Theory and Practice, 13 (2), 4-19.

Nada, N. and Ali, Z. (2015). Service Value Creation Capability Model to Assess the Service Innovation Capability in SMEs. 7th Indistrial Product Service Systems Conference PSS Industry transformation for Sustainability and Business Procedia CIRP, 30, 390-395.

Narver, J. C. and Slater, S. F. (1990). The Effect of a Market Orientation on Business Profitability. Journal of Marketing, 54 (4), 20-35.

Olson, E. M., Slater, S. F. and Hult, G. T. M. (2005). The Performance Implications of fit among Business Strategy Marketing Organization Structure and Strategic Behavior. Journal of Marketing, 69 (3), 49-65.

Papatya, G., Papatya N. ve Hamşığlu, A.B. (2014). Yenilik Üretme Yeteneğinin İşletme Performansına Etkisi ve Bir Uygulama. 8-10 Mayıs 2014 Antalya 13. Ulusal Işsletmecilik kongresi Bildiri Kitabı, C. 2, Marmara Ünv. Yayınevi, 1067-1074.

Papatya, N. (2002). Gelecek Rekabetinin Yeni Konsepti: Kaynak Tabanlılık Görüşü. İnfomag İletişim ve Bilişim Dergisi, 22 (Ağustos), 59-61.

Papatya, N. (2003). Kaynak Tabanlı Görüş. Ankara: Nobel Ya.

Papatya, N. (2006a). İşletmelerde Sıradışı Rekabet için Yenilikçi Pazarlama Yaklaşımı. Pazarlama Dünyası Dergisi, 20, 4 (Temmuz-Ağustos), 42-46.

Papatya, N. (2006b). İşletmelerde Rekabetçi Zekânın Değişen Yüzü: Girişimci Pazarlama. Pİ-Pazarlama iletişim Kültür Dergisi-Medicat, 5, 16 (Nisan-Mayıs-Haziran 2006/2), 45-59.

Papatya, N. ve Papatya, G. (2007). İşletmelerde Rekabetçi Zekâ Nasıl Yaratılabilir?: Türkiye Tekstil Sektörüne İlişkin Değerlendirme ve Bir Model Önerisi. 25-27 Mayıs 2007 Sakarya Ünv. 15. Yönetim ve Organizasyon Kongre Bildiri Kitabı, 368-379.

Persson, G. (1991). Achieving Competitiveness through Logistics. International Journal of Logistics Management, $2(1), 1-11$.

Peters, T. J. (1984). Strategy follows Structure: Developing Distinctive Skills. California Management Review, 26 (3), 111-125.

Porter, M. E. (1985). Competitive Avdantage, The Free Press, New York, NY.

Porter, M. E. (1998). Competitive Advantage, Creating and Sustaining Superior Performance. New York: Free Press, London

Rajapathirana, R. P. and Hui, Y. (2018). Relationship between Innovation Capability, Innovation type and Firm Performance., Journal of Innovation Knowledge, 3, 44-55.

Richey, R. G., Daugherty, P. J., Genchev, S. E. and Autry, C.,W. (2004). Reverse Logistics: The Impact of Timing and Resources. Journal of Business Logistics, 25 (2), 229-270.

Rogers, E. M. (1983). Diffusion of Innovations. Third Edition, The Free Press, New York.

Sinkovics, R. R. and Roath, A. S. (2004). Strategic Orientatiion Capabilities and Performance in Manufacturer3PL Relatiponship. Journal of Business Logistics, 25 (2), 43-64.

Sinkula, J. M. (1994). Market Information Processing and Organizational Learning. Journal of Marketing, 58 (1), $35-45$.

Ta-Wei, T., Wang M., Hung, C. and Ya-Yun, T. (2015). Developing Service Innovation Capability in the Hotel Industry. Service Business, 9, 97-113. 
N. Papatya - G. Papatya - B. Hamşığlu 12/4 (2020) 4051-4064

Teece, D. J. (1998). Capturing Value from Knowledge Assests: The New Economy Markets for Know-how and Intangible Assets. California Management Review, 40 (3), 55-79.

Theodosiou, M., Kehagias J. and Katsikea, E. (2012). Strategic Orientation, Marketing Capabilities and Firm Performance: An Emprical Investigation in the Context of frontline Managers in Service Organizations. Industrial Marketing Management, 41, 1058-1070.

Turner, K. L. and Makhija, M. K., (2006). The role of Organizational Control in Managing Knowledge. The Academy of Management Review, 31 (1), 197-217.

Venkatraman, N. and Ramanujam, V. (1986). Measurement of Business Performance in Strategy Research: A Comparison of Approaches. Academy of Management Review, 11 (4), 801-814.

Wong K. K. K. (2013). Partial Least Squares Structural Equation Modeling (PLS-SEM) Techniques Using SmartPLS. Technical Note 1, Marketing Bulletin, 24, 1-32.

Woodruff, R. B. (1997). Customer Value: The Next Source for Competitive Advantage. Journal of the Academy of Marketing Science, 25 (2), 139-153.

Yasin, M. M., Bayes, P. E., and Czurchry, A. J. (2005). The Changing role of Accounting in Supporting the Quality and Customer Goals of Organizations: An Open System Perspective. International Journal of Management, 22 (3), 323-331.

Zander, U. and Kogut, B. (1995). Knowledge and the Speed of the Transfer and Imitation of Organizational Capabilities: An Emprical Test. Organization Science, 6 (1), 76-92.

Zhou, K. Z. and Li, C. B. (2010). How Strategic Orientations Influence the Building of Dynamic Capability in Emerging Economies. Journal of Business Research, 63, 224-231. 